\title{
Dexamethasone and infection in preterm babies: a controlled study
}

\author{
P C Ng, M A Thomson, P R F Dear
}

\begin{abstract}
To find out if the usc of steroids affected the incidence of infection in babies who were nursed in the neonatal intensive care unit for nine weeks or more, 24 preterm babies who had received a three weeks course of dexamethasone $(0.6 \mathrm{mg} / \mathrm{kg} / \mathrm{day}$, reducing to $0.3 \mathrm{mg} / \mathrm{kg} / \mathrm{day}$ after a week, and $0.15 \mathrm{mg} / \mathrm{kg} /$ day after two weeks) were compared with 18 preterm babies who had not been so treated. No differences were found in the incidence or pattern of septicaemia or other bacteriologically proved infections between the groups. Of 57 episodes of septicaemia, $44(77 \%)$ were caused by coagulase negative staphylococci.
\end{abstract}

Corticosteroids are being used increasingly to treat bronchopulmonary dysplasia in preterm babies.

The two most serious side effects of treatment with steroids are suppression of the hypothalamic-pituitary-adrenal axis, and predisposition to infection. Neither has been fully evaluated with specific reference to preterm babies, although some information about adrenal suppression is emerging. An association between treatment with steroids and infection is generally assumed in adult patients, but we have not observed either any increase in our overall incidence of infection, or any change in the nature of the infecting organisms, since we started using dexamethasone regularly in the treatment of bronchopulmonary dysplasia. To see if our impression was correct, we compared the incidence and nature of infections in a group of babies treated with steroids and a group of matched controls.

\section{Patients and methods}

The study took place between January 1987 and December 1988. The treatment group comprised 24 preterm babies who had received a three week course of dexamethasone and remained on the neonatal unit for at least nine weeks. The course began with $0.6 \mathrm{mg} / \mathrm{kg} / \mathrm{day}$, reducing to half this dose at the end of one week, and to a quarter of it at the end of two weeks. The control group comprised 18 preterm babies who were not treated with steroids, but were ventilated for at least two weeks and also remained on the neonatal unit for more than nine weeks. Babies selected to receive dexamethasone were those who were dependent on ventilators because of chronic lung disease, and in whom no appreciable reduction in ventilator settings had been poss- ible over a period of a week. Babies in the control group, although they also had chronic lung disease, were all showing a steady improvement in lung function and so were not considered to need treatment with steroids.

The study was designed to compare the incidence and cause of septicaemia in the two groups during equivalent periods of time. To allow for a secular change in the susceptibility of the babies to infection as a result of increasing maturity and improving health, we compared the postnatal age of the two groups. As the median postnatal age at which steroids were started was 21 days (mean 24 days), we defined three periods of time of three weeks each in which to make both the 'within-group' and the 'between-group' comparisons. These were the first three weeks of life (before steroids in the treatment group), the second three weeks of life (while steroids were being given to the treatment group), and the third three weeks of life (immediately after the steroid treatment had finished). Statistical comparisons were made between corresponding three week periods in the two groups, and between different three week periods in the same group.

All suspected episodes of infection were investigated and documented. Septicaemia was diagnosed when the same organism was isolated from both blood culture bottles, and each isolate showed an identical pattern of antibiotic sensitivity and biochemical profile. Bacteriologically confirmed infections other than septicaemia, such as pneumonia, peritonitis, meningitis, necrotising enterocolitis, and fungal infections were also documented.

An unpaired $t$ test was used to assess the significance of differences in the clinical characteristics between the two groups of babies, and the $\chi^{2}$ test to assess those differences in the incidence of septicaemia and bacteriologically confirmed infections other than septicaemia, both 'within-groups' and 'between-groups'. Permission was obtained from parents in all cases.

\section{Results}

Table 1 shows the characteristics of the two groups of babies. For each variable compared the $\mathrm{p}$ value is greater than $0 \cdot 25$.

Tables 2 and 3 show the incidence and cause of septicaemic episodes in the treated and control groups. In all the between group comparisons the $p$ values are greater than 0.35 , and in all the within group comparisons the $p$ values are greater than 0.08 . There is a lower incidence of infection during the third three week period within each group, but this is not significant. 
Table 1 Comparability of the groups

\begin{tabular}{|c|c|c|c|c|}
\hline & \multicolumn{2}{|c|}{$\begin{array}{l}\text { Group treated with } \\
\text { dexamethasone }(n=24)\end{array}$} & \multicolumn{2}{|c|}{ Control group $(n=18)$} \\
\hline & Mean (SD) & Median & Mean $(S D)$ & Median \\
\hline $\begin{array}{l}\text { Gestational age (weeks) } \\
\text { Birth weight }(\mathrm{g}) \\
\text { Temperature on admission }\left({ }^{\circ} \mathrm{C}\right) \\
\text { Apgar score at one minute } \\
\text { Apgar score at five minutes } \\
\text { No of days receiving assisted ventilation } \\
\text { No of days dependent on supplementary oxygen }\end{array}$ & $\begin{aligned} & 27 \cdot 7(2 \cdot 0) \\
& 1041(292) \\
& 35 \cdot 8(1 \cdot 0) \\
& 4 \cdot 0(2 \cdot 4) \\
& 7 \cdot 8(1 \cdot 6) \\
& 26 \cdot 5(16 \cdot 8) \\
& 69 \cdot 9(44 \cdot 4)\end{aligned}$ & $\begin{array}{r}27 \cdot 5 \\
978 \\
36 \cdot 0 \\
4 \cdot 0 \\
8 \cdot 0 \\
24 \cdot 5 \\
54 \cdot 0\end{array}$ & $\begin{array}{l}27 \cdot 2(1 \cdot 9) \\
1032(196) \\
35 \cdot 5(0 \cdot 7) \\
3 \cdot 7(2 \cdot 6) \\
7 \cdot 5(1 \cdot 3) \\
29 \cdot 1(15 \cdot 6) \\
58 \cdot 3(27 \cdot 5)\end{array}$ & $\begin{array}{r}27 \cdot 0 \\
1073 \\
35 \cdot 5 \\
3 \cdot 0 \\
7 \cdot 0 \\
24 \cdot 0 \\
51 \cdot 5\end{array}$ \\
\hline Male:female ratio & \multicolumn{2}{|c|}{$13: 11$} & \multicolumn{2}{|c|}{$8: 10$} \\
\hline
\end{tabular}

Table 2 Incidence of septicaemia in the two groups in each of the three time periods

\begin{tabular}{|c|c|c|c|c|c|c|}
\hline & \multicolumn{3}{|c|}{ Group treated with dexamethasone $(n=24)$} & \multicolumn{3}{|c|}{ Control group $(n=18)$} \\
\hline & $\begin{array}{l}\text { Weeks } \\
1-3\end{array}$ & $\begin{array}{l}\text { Weeks } \\
4-6\end{array}$ & $\begin{array}{l}\text { Weeks } \\
5-9\end{array}$ & $\begin{array}{l}\text { Weeks } \\
1-3\end{array}$ & $\begin{array}{l}\text { Weeks } \\
4-6\end{array}$ & $\begin{array}{l}\text { Weeks } \\
5-9\end{array}$ \\
\hline $\begin{array}{l}\text { No }(\%) \text { who had two episodes of septicaemia } \\
\text { No (\%) who had one episode of septicaemia } \\
\text { No (\%) who did not develop septicaemia }\end{array}$ & $\begin{array}{ll}1 & (4) \\
11 & (46) \\
12 & (50)\end{array}$ & $\begin{array}{l}1(4) \\
10(42) \\
13(54)\end{array}$ & $\begin{aligned} 1 & (4) \\
4 & (17) \\
19 & (79)\end{aligned}$ & $\begin{array}{l}3(17) \\
6(33) \\
9(50)\end{array}$ & $\begin{array}{l}1(6) \\
9(50) \\
8(44)\end{array}$ & $\begin{aligned} 0 \\
4(22) \\
14(78)\end{aligned}$ \\
\hline Total No of episodes of septicaemia & 13 & 12 & 6 & 12 & 11 & 4 \\
\hline
\end{tabular}

Table 3 Number (\%) of organisms isolated from blood in 58 episodes of septicaemia

\begin{tabular}{|c|c|c|c|c|c|c|}
\hline & \multicolumn{3}{|c|}{ Group treated with dexamethasone $(n=24)$} & \multicolumn{3}{|c|}{ Control group $(n=18)$} \\
\hline & $\begin{array}{l}\text { Weeks } \\
1-3\end{array}$ & $\begin{array}{l}\text { Weeks } \\
4-6\end{array}$ & $\begin{array}{l}\text { Weeks } \\
5-9\end{array}$ & $\begin{array}{l}\text { Weeks } \\
1-3\end{array}$ & $\begin{array}{l}\text { Weeks } \\
4-6\end{array}$ & $\begin{array}{l}\text { Weeks } \\
5-9\end{array}$ \\
\hline Total No of episodes of septicaemia & 13 & 12 & 6 & 12 & 11 & 4 \\
\hline $\begin{array}{l}\text { Organism: } \\
\text { Coagulase negative staphylococcus } \\
\text { Streptococcus faecalis } \\
\text { Staphylococcus aureus } \\
\text { Bacteroides } \mathrm{spp} \\
\text { Acinetobacter spp } \\
\text { Neisseria gonorrhoeae } \\
\text { Haemophilus influenzae } \\
\text { Candida spp }\end{array}$ & $\begin{array}{ll}8 & (62) \\
2 & (15) \\
1 & (8) \\
1 & (8) \\
0 & \\
0 \\
0 \\
1(8)\end{array}$ & $\begin{array}{l}11(92) \\
0 \\
0 \\
0 \\
0 \\
0 \\
0 \\
1(8)\end{array}$ & $\begin{array}{l}5(83) \\
0 \\
0 \\
0 \\
1 \\
0 \\
0 \\
0\end{array}$ & $\begin{array}{l}9 \\
0 \\
0 \\
0 \\
0 \\
1(75) \\
1(8) \\
1(8) \\
0\end{array}$ & $\begin{array}{ll}9 & (82) \\
1 & (9) \\
1 & (9) \\
0 \\
0 \\
0 \\
0 \\
0\end{array}$ & $\begin{array}{l}2(50) \\
0 \\
0 \\
0 \\
1(25) \\
0 \\
0 \\
1(25)\end{array}$ \\
\hline
\end{tabular}

Coagulase negative staphylococci were the organisms most frequently isolated, causing 44 of the $57(77 \%)$ of the episodes of septicaemia. All the episodes occurred when at least one intravascular cannula was in place.

When bacteriologically confirmed infections other than septicaemia were included, the difference in the incidence of infection 'between-groups' and 'within-groups' was not significant ( $p>0.35$ and $p>0.06$, respectively). The third three week period in both groups again tended to have a lower incidence of infection when compared with the preceding six weeks. Pneumonia confirmed by bacteriology $(n=6)$ was the second commonest infection after septicaemia. Fungal infection $(n=1)$, necrotising enterocolitis $(n=2)$, peritonitis $(n=1)$, and cytomegalovirus infection acquired from transfusion $(n=1)$ were evenly distributed between the two groups.

\section{Discussion}

The mechanisms by which steroids might predispose to infection are not clear. Recent work points to an effect on leucocyte kinetics causing eosinopenia, lymphocytopenia, monocytopenia, and neutrophilia. ${ }^{1}$ The neutrophilia is caused by a shift of neutrophils from the marginal pool into the blood stream and is accompanied by a blunting of the chemotactic response.

The extent to which steroids truly predispose to infection is, however, overestimated. ${ }^{12}$ Several studies have shown little or no increase in the incidence of infection among steroid treated adults compared with controls,,${ }^{1-4}$ as did the only single small study in neonates that we could find.

One explanation for the apparent increase in infection in patients treated with steroids is the influence of the underlying disease or state of the patient. Preterm babies are all immunocompromised to some extent, and have poor neutrophil chemotaxis, so that steroids may impose little further increase in risk.

Another factor is that many infections in both children and adults treated with steroids are reactivations of latent infection, probably the result of lymphopenia and monocytopenia. ${ }^{1}$ In newborn infants, infections are the result of new bacterial invasion, often directly into the blood stream through an intravascular line; this process is uninfluenced by steroids. ${ }^{1}$

Also relevant to the results of our study is the fact that the anti-inflammatory potency of a parti- 
cular steroid has little influence on its immunosuppressive effect. Dexamethasone, which is one of the most potent corticosteroids, has comparatively little immunosuppressive property. ${ }^{6}$

The results of our study show that the use of dexamethasone in the treatment of bronchopulmonary dysplasia is not associated with an appreciable increase in the incidence of infection, although the possibility of a Type II error prevents us from ruling out a small effect. Steroids should not be withheld for fear of predisposing to infection.
1 Mukwaya G. Immunosuppressive effects and infections associated with corticosteroid therapy. Pediatr Infect Dis $\mathcal{J}$ 1988; 7:499-504.

2 Lepper MH. Prophylaxis in patients receiving adrenal steroid therapy. F Chronic Dis 1962;15:691-711.

3 Kwong FK, Sue MA, Klaustermeyer WB. Corticosteroid complications in respiratory disease. Ann Allergy 1989; $58: 326-30$.

4 Anderson R, Malmwall BE, Bengtsson BA. Long term corticosteroid treatment in giant cell arteritis. Acta Med Scand 1986;220:465-9.

5 Fitzhardinge PM, Eisen A, Lejtenyi C, Metrakos K, Ramsay $M$. Sequelae of early steroid administration to the newborn infant. Pediatrics 1974;53:877-83.

6 Langhoff E, Ladefoged J. Relative immunosuppressive potency of various corticosteroids measured in vitro. Eur f Clin Pharmacol 1983;25:454-62.

\title{
Neonatal pneumomediastinum with isolated mitral obstruction
}

\author{
C L Case, P Oslizlok, D Fyfe, P C Gillette
}

\begin{abstract}
While mediastinal air accumulation in the ventilated newborn is usually a benign entity, tension pneumomediastinum can embarrass both respiratory and cardiac function. A case of isolated left ventricular inflow obstruction caused by a pneumomediastinum in a premature infant is described that resolved with high frequency ventilation. The development of pneumomediastinum and haemodynamic compromise in a premature infant warrants echocardiographic examination.
\end{abstract}

Intrathoracic air accumulation is a common complication of mechanical ventilation in the newborn intensive care unit. The clinical consequences of pneumomediastinum and pulmonary interstitial emphysema in the premature infant have been well described. ${ }^{12}$ Pneumomediastinum is a less commonly encountered result of barotrauma, often having minimal pulmonary or cardiac consequences. We here describe a case of pneumomediastinum in a low birthweight premature infant that caused haemodynamic compromise secondary to isolated left ventricular inflow obstruction. High frequency ventilation was successfully used to decompress the mediastinum and restore normal cardiac function.

South Carolina
Children's Heart Center,
Medical University of
South Carolina
C Case
P Oslizlok
D Fyfe
P C Gillette
Correspondence to:
Dr C L Case,
South Carolina
Children's Heart Center,
Medical University of
South Carolina,
171 Ashley Avenue,
Charleston, SC 29425,
USA.
Accepted 7 September 1989

\section{Case report}

A boy, weighing $750 \mathrm{~g}$, was born vaginally at 25 weeks' gestation to a 23 year old woman (gravida 4, para 3) with an uncomplicated prenatal course. Labour was spontaneous and Apgar scores were 4 at 1 minute and 5 at 5 minutes with immediate intubation in the delivery room. During the first 12 hours of life, the patient required increasing ventilator rates and pressures secondary to severe hyaline membrane disease. A small patent arterial duct was diagnosed by echocardiography at 12 hours of age and indomethacin treatment was instituted.

During the next 12 hours, the ventilatory peak pressures and rates were modestly weaned. The infant's chest radiograph, however, showed signs of worsening disease with the appearance of interstitial emphysema. During the second day of life there were increasing ventilator requirements. Peak ventilatory pressures of $30 \mathrm{~cm} \mathrm{H}_{2} \mathrm{O}$ (mean airway pressure of $17 \mathrm{~cm}$ $\mathrm{H}_{2} \mathrm{O}$ ) and rates of 70 breaths/minute and $100 \%$ oxygen were needed to maintain a $\mathrm{pH}$ of $7 \cdot 24$, a carbon dioxide arterial pressure of $7 \cdot 8 \mathrm{kPa}$ and an oxygen arterial pressure of $7.8 \mathrm{kPa}$.

On day three of life, the patient continued to require maximal respiratory support. A chest radiograph showed free air in the mediastinum and increasing opacity of the lung fields (fig la). Subcutaneous emphysema was also noted. Repeat echocardiography was performed to assess the efficacy of the indomethacin treatment. Pulsed Doppler examination confirmed that the arterial duct had closed. The four chamber view, however, showed a large mass like effect superior and posterior to the left atrium (fig lb). Pulsed Doppler examination showed evidence of inflow obstruction at the mitral valve with turbulent flow and a peak inflow velocity of $100 \mathrm{~cm} / \mathrm{second}$ (fig lc). Simultaneous tricuspid inflow was laminar with a peak inflow velocity of $20 \mathrm{~cm} /$ second (fig ld). Postulating that a tension pneumomediastinum was compromising mitral inflow and possibly contributing to pulmonary oedema, strategies to decompress the mediastinum were considered. In view of the infant's precarious condition, surgical decompression was thought to be too risky. High frequency jet ventilation at a rate of 420 breaths/minute was instituted and a reduction of mean airway pressure from 17 to $8 \mathrm{~cm} /$ $\mathrm{H}_{2} \mathrm{O}$ was effected.

Over the next 12 hours, the infant's chest radiograph showed resolution of mediastinal air (fig 2a) with concurrent improvement in arterial 